\title{
AUDIO-VESTIBULAR FINDINGS IN AN ADULT WITH ARNOLD-CHIARI MALFORMATION
}

\section{Prashanth Prabhu A-F, Anu Sara Anish ${ }^{A-F}$, Devika Vijayan ${ }^{A-F}$, Annika Mariam Shiju ${ }^{A-F}$, Shanthala SPA-C,F, Ramadevi Sreenivas ${ }^{A, D-F}$}

Department of Audiology, All India Institute of Speech and Hearing, India

Corresponding author: Prashanth Prabhu; Department of Audiology, All India Institute of Speech and Hearing, Naimisham Campus, Manasagangothri, 570006, Mysore, India; email: prashanth.audio@gmail.com; Phone: +91 8904353390

\section{Abstract}

Background: Arnold-Chiari malformation is defined as a congenital neuroanatomic deformity of the craniocervical junction, which is characterized by herniation of contents from the posterior cranial fossa through the foramen magnum into the cervical spinal canal. There is limited literature on audiological and vestibular evaluation on individuals with Arnold-Chiari malformation. Thus, the present study reports the results of a detailed audio-vestibular evaluation in an adult female diagnosed with Arnold-Chiari malformation.

Case report: A detailed audio-vestibular evaluation was carried out in an adult female diagnosed with Arnold-Chiari malformation. Pure tone audiometry, immittance evaluation, otoacoustic emissions, auditory brainstem response (ABR), cervical vestibular evoked myogenic potential (cVEMP), ocular vestibular evoked myogenic potential (oVEMP), and video head impulse test (vHIT) were recorded, and the results were analyzed. The results of the study showed an abnormal prolongation of inter-peak latencies in the ABR, which was seen in both ears. Also, cVEMP and oVEMP was absent in both ears. The results suggest possible compression of the cerebellar tonsils on the cochlear and vestibular nuclei.

Conclusions: The study suggests that individuals with Arnold-Chiari malformation should undergo a detailed audio-vestibular evaluation to understand the pathophysiology of the disorder, which can guide further management.

Key words: ABR • Arnold-Chiari malformation • cVEMP • oVEMP • vHIT

\section{WYNIKI SŁUCHOWO-PRZEDSIONKOWE U OSOBY DOROSŁEJ Z ZESPOŁEM ARNOLDA-CHIARIEGO}

\begin{abstract}
Streszczenie
Wstęp: Zespół Arnolda-Chiariego jest wrodzoną neuroanatomiczną deformacją połączenia czaszkowo-szyjnego, która charakteryzuje się przepukliną od tylnego dołu czaszki przez otwór wielki do odcinka kanału znajdującego się w kręgosłupie szyjnym. Istnieje niewiele pozycji literatury na temat stanu audiologicznego i przedsionkowego pacjentów z zespołem Arnolda-Chiariego. Niniejsze badanie przedstawia wyniki szczegółowej oceny słuchowo-przedsionkowej u dorosłej kobiety z zespołem Arnolda-Chiariego.

Opis przypadku: Szczegółowe badania słuchowo-przedsionkowe przeprowadzono u dorosłej kobiety, u której zdiagnozowano zespół ArnoldaChiariego. Wykonano następujące badania: audiometrię tonalną, ocenę impedancji, badanie emisji otoakustycznych, badanie odpowiedzi słuchowych pnia mózgu (ABR), zapis szyjnych miogennych przedsionkowych potencjałów wywołanych (cVEMP), zapis ocznych miogennych przedsionkowych potencjałów wywołanych (oVEMP) oraz próby kaloryczne (vHIT). Wyniki zostały poddane analizie. Badanie ABR wykazało nieprawidłowe wydłużenie latencji między szczytami dla obu uszu. Natomiast cVEMP i oVEMP nie wystąpiły w obojgu uszach. Wyniki wskazują na możliwy ucisk migdałków móżdżku na rdzeń ślimakowy i przedsionkowy.
\end{abstract}

Wnioski: Badanie dowodzi, że u osób z zespołem Arnolda-Chiariego należy przeprowadzić szczegółowe badania słuchowo-przedsionkowe, aby zrozumieć patofizjologię zaburzenia i ukierunkować dalsze postępowanie kliniczne.

Słowa kluczowe: ABR • zespół Arnolda-Chiariego • cVEMP • oVEMP • vHIT

\section{Introduction}

Arnold-Chiari malformation is defined as a congenital neuroanatomic deformity of the craniocervical junction, which is characterized by herniation of contents from the posterior cranial fossa through the foramen magnum into the cervical spinal canal [1,2]. The cause of Arnold-Chiari malformation can be primary or secondary. The primary causes include genetic mutation and a maternal diet that lacked certain vitamins, whereas secondary causes include traumatic brain injury and infection. Arnold-Chiari malformation is classified into four major types depending on the extent and degree of herniation of the neural contents of the posterior cranial fossa.
The symptoms of Type I Arnold-Chiari malformation include sub-occipital headache and neck pain aggravated by Valsalva manoeuvers, cerebellar symptoms like nystagmus, and symptoms of affected cranial nerve nuclei. The audiovestibular symptoms include positional vertigo, tinnitus, sensorineural hearing loss, and nystagmus [3]. Common symptoms in individuals with Arnold-Chiari malformation include pain around the neck and head, muscle atrophy with associated motor weakness, and cranial nerve neuropathies [4]. In addition to neurological symptoms, several audio-vestibular symptoms are reported in individuals with Arnold-Chiari malformation. The symptoms include headache (suboccipital), tinnitus, vertigo (positional), nystagmus, and sensorineural hearing loss; 
in advanced stages palsies of cranial nerves $\mathrm{V}$ through XII can also occur [5-7].

There is limited literature on audiological and vestibular evaluation on individuals with Arnold-Chiari malformation. A detailed audio-vestibular evaluation might shed light on the possible pathophysiology for these symptoms, and here a test battery including pure tone audiometry, speech audiometry, immittance evaluation, otoacoustic emission (OAE), auditory brainstem response (ABR), cervical vestibular evaluation (cVEMP), ocular vestibular evoked myogenic potential (oVEMP) and video head impulse test (vHIT) is used. Thus, the present clinical case study attempts to report the results of a complete audiovestibular evaluation in an adult female diagnosed with Arnold-Chiari malformation.

\section{Methods}

A 40 year old female reported to the audiology clinic with a complaint of reduced hearing sensitivity in both ears. The patient reported intermittent bilateral tinnitus in both ears. She also reported giddiness, headache, and positional vertigo. The onset of the symptoms suddenly appeared 6 months ago. She was referred for detailed audiological evaluation: pure tone audiometry, speech audiometry, immittance evaluation, $\mathrm{OAE}$, and $\mathrm{ABR}$ using the standard test protocols.

Pure tone audiometry was done for both ears using puretone frequencies of $250 \mathrm{~Hz}$ to $8 \mathrm{kHz}$ for air conduction thresholds and frequencies of $250 \mathrm{~Hz}$ to $4 \mathrm{kHz}$ for bone conduction thresholds. Speech identification scores were determined using standardized phonemically balanced words in the Kannada language [8]. A speech perception in noise (SPIN) test was administered at $0 \mathrm{~dB}$ SNR. She was also evaluated for tinnitus through pitch matching, intensity matching, and residual inhibition. Immittance evaluation was carried out for both ears using a probe tone frequency of $226 \mathrm{~Hz}$ and acoustic reflex thresholds were obtained at $0.5,1,2$, and $4 \mathrm{kHz}$ for both ipsilateral and contralateral stimulation. Both transient evoked otoacoustic emissions (TEOAEs), and distortion product otoacoustic emissions (DPOAEs) were done to gauge outer hair cell functioning. Following this, an ABR (site of lesion) was done using $100 \mu$ s rarefaction clicks at repetition rates of $11.1 / \mathrm{sec}$ and $90.1 / \mathrm{sec}$, filter settings of $100 \mathrm{~Hz}$ to $3 \mathrm{kHz}$ and fixed intensity of $90 \mathrm{~dB} \mathrm{nHL}$. The electrodes were placed conventionally $(\mathrm{M} 1-\mathrm{Cz}-\mathrm{M} 2)$

A detailed case history regarding vestibular symptoms was taken. cVEMP, oVEMP, and vHIT were recorded using standard protocols [9-11]. To activate the ipsilateral sternocleidomastoid muscle during cVEMP recording, the patient was instructed to sit straight and turn the head to the opposite side of stimulation. The electrodes were placed in such a way that the non-inverting electrode (+) was placed in the midpoint of the sternocleidomastoid muscle of the side being stimulated, the inverting electrode (-) in the sternoclavicular junction, and the ground electrode was placed on the lower forehead. cVEMPs were recorded using $500 \mathrm{~Hz}$ tone bursts ( 2 cycles rise, 0 cycles plateau, and 2 cycles fall, Blackman window) at a rate of 5.1/s using rarefaction polarity at $95 \mathrm{dBnHL}$. A high pass filter of $30 \mathrm{~Hz}$ and a low pass filter of $1500 \mathrm{~Hz}$ was used. The responses were averaged for a total of 200 stimuli.

To obtain an oVEMP, the client was instructed to maintain an upper gaze. The electrodes were placed on the side contralateral to the stimulated ear. The inverting electrode was placed below the lower eyelids of the contralateral eye to the side being stimulated, the non-inverting electrode $(+)$ was placed immediately inferior to the inverting electrode, and the ground electrode was placed on the lower forehead. Tone bursts of $500 \mathrm{~Hz}$ at a rate of $5.1 / \mathrm{s}$ in rarefaction polarity were used as the stimulus at $95 \mathrm{~dB} \mathrm{nHL}$. The recorded responses were amplified $(\times 5000)$ and filtered using a high pass filter of $1 \mathrm{~Hz}$ and a low pass filter of $1000 \mathrm{~Hz}$. Response averaging was done for 200 stimuli.

The video head impulse test was done in a well-lit room using dedicated OTOsuite vestibular software (GN Otometrics, Taastrup, Denmark). Light-weight goggles with Frenzel glasses were fixed in place to avoid slippage. After calibration, head thrusts were applied for lateral plane, right anterior / left posterior plane (RALP), and left anterior / right posterior plane (LARP). Head thrusts were applied at an angle of $10-15^{\circ}$ in all three orthogonal planes (pitch, roll, and yaw) randomly. VOR gain was measured for all six semicircular canals and the refixation saccades (if any) at the time of head thrust (covert saccade) and after the head thrust (overt saccade) were analyzed. The patient was referred for further neurological evaluation at the same clinic, and the magnetic resonance imaging (MRI) was performed. Informed consent was obtained from the patient to participate in the study.

\section{Results}

The clinical neurological evaluation and MRI revealed that the cerebellar tonsils were located $7 \mathrm{~mm}$ caudal to the level of the foramen magnum, in keeping with Type I Arnold-Chiari malformation. The results of the audiological evaluation showed that the patient had bilateral moderate sloping sensorineural hearing loss. The pure tone average of right and left ear was 50 and $55 \mathrm{~dB}$ HL, respectively. The speech identification scores were $92 \%$ in the right ear and $88 \%$ in the left. The SPIN scores in the right and left ears were $60 \%$ and $52 \%$. She had an 'As' type tympanogram with absent acoustic reflexes in both ears. Otoacoustic emissions - both transient evoked OAE (TEOAE) and distortion product OAE (DPOAE) -were absent in both ears, indicating bilateral outer hair cell dysfunction. ABR-SOL was done, and inter-peak latency of $\mathrm{I}-\mathrm{V}$ was prolonged in both ears and inter-peak latency I-III was prolonged in the left ear, suggestive of bilateral retrocochlear pathology. The latencies of waves I, III, and V in the right ear were $1.58,3.70$, and $5.82 \mathrm{~ms}$ respectively. The interpeak latencies of I-III, III-V, and I-V were 2.12, 2.12, and $4.24 \mathrm{~ms}$ respectively in the right ear. Similarly, the absolute latencies of waves I, III, and V in the left ear were $1.49,3.70$, and $5.86 \mathrm{~ms}$ respectively. The inter-peak latencies of I-III, III-V, and I-V were $2.21,2.16$, and $4.37 \mathrm{~ms}$ respectively in the left ear. The wave $\mathrm{V}$ latency at $90.1 \mathrm{~Hz}$ repetition rate was 6.36 and $6.53 \mathrm{~ms}$ in the 
right and left ear separately. The ABR waveform of the right and left ears is shown in Figure 1 and Figure 2, respectively.

The patient matched the pitch of her tinnitus to $4-8 \mathrm{kHz}$, the intensity to $25 \mathrm{~dB}$ SL, and the residual inhibition was positive and complete. The vestibular evaluation showed that she had absent cVEMP and oVEMP in both ears. This suggested an abnormal sacculocollic pathway and utriculo-ocular pathway in both ears. The cVEMP and oVEMP waveforms are shown in Figure 3 and Figure 4, respectively.

The results of vHIT revealed normal functioning of all three semicircular canals in both ears, as shown in Figure 5.

\section{Discussion}

The results of the study showed that the patient had bilateral moderate sensorineural hearing loss. Previous studies on Arnold-Chiari malformation have also reported sensorineural hearing loss [13]. Rydell and Pulec [5] reported that 13 out of 130 individuals with Arnold-Chiari malformation had hearing loss. They reported that the incidence of bilateral hearing loss was more common than unilateral loss. The duration of hearing loss ranged from months to years. It was also reported that the degree of hearing loss was proportional to the severity of associated problems [5]. Hendrix et al. [12] evaluated three patients with a complaint of asymmetrical sensorineural hearing loss. Magnetic resonance imaging revealed the presence of ArnoldChiari type 1 malformation. Hearing loss was progressive in all three patients.

Rydell and Pullec [5] reported the possible reasons for hearing the loss in individuals with Arnold-Chiari malformation: stretching of congenitally elongated $8^{\text {th }}$ cranial nerve as the brain stem shifts caudally; compression of the $8^{\text {th }}$ cranial nerve over the bony edge of porus acusticus as it descends to caudally depressed nuclei; and direct compression of the brainstem nuclei by the cerebellar tonsils.

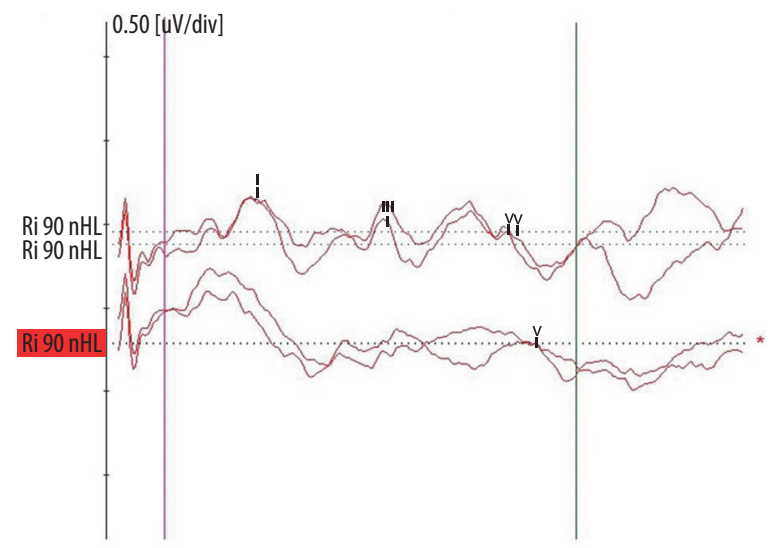

Figure 1. Auditory brainstem response of the right ear for the patient. X-axis is time in milliseconds and Y-axis is amplitude in microvolt. It indicates prolonged interpeak latencies of $\mathrm{I}-\mathrm{V}$, indicating a possible retrocochlear pathology

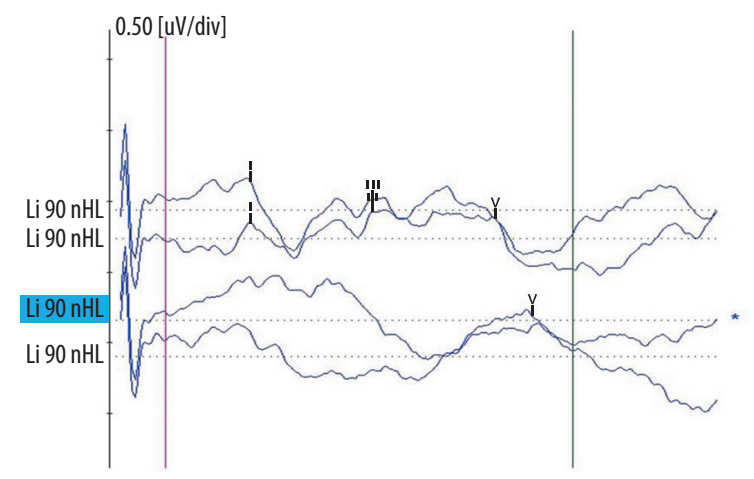

Figure 2. Auditory brainstem response of left ear for the patient. It indicates prolonged inter-peak latencies of I-V, indicating a possible retrocochlear pathology

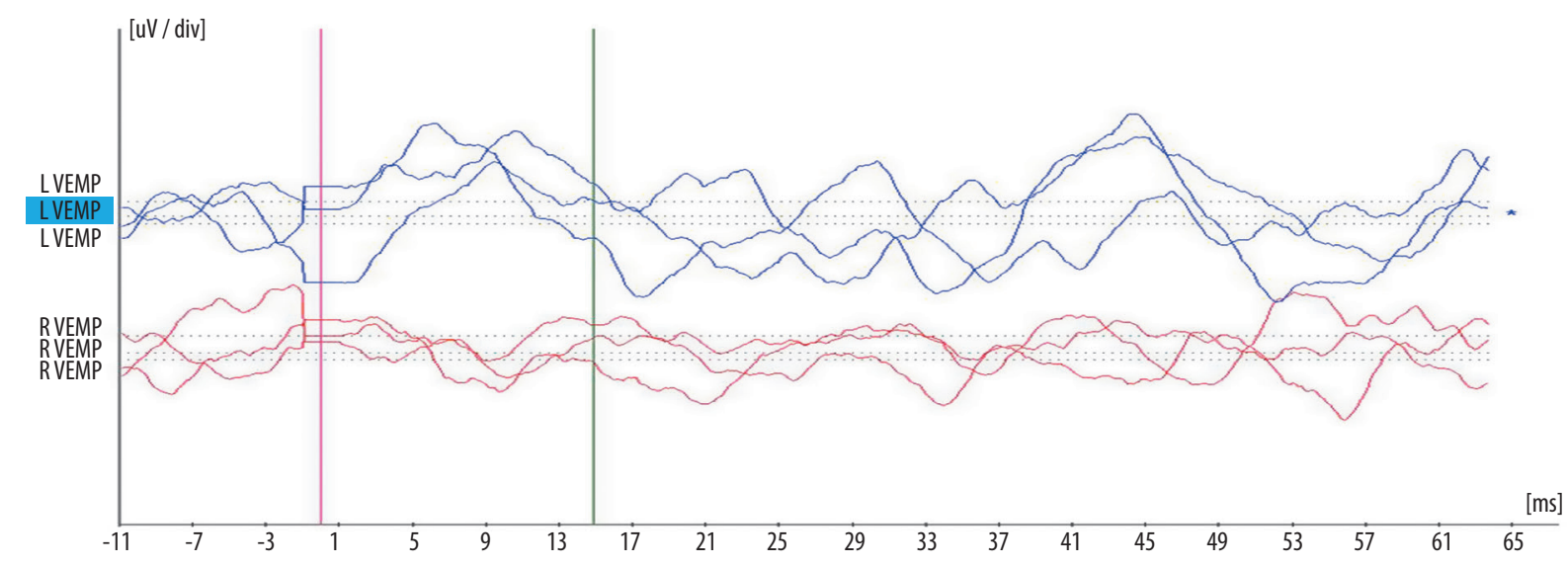

Figure 3. Cervical vestibular evoked myogenic potential of the patient in both ears. The absent cVEMP indicates dysfunction of the sacculo-collic pathway 


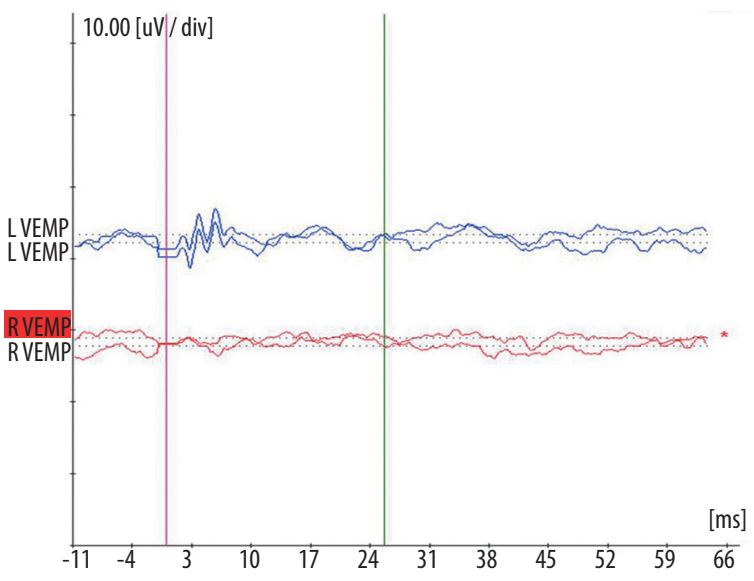

Figure 4. Ocular vestibular evoked myogenic potential of the patient in both ears. The absent oVEMP indicates dysfunction of the utriculo-ocular pathway

The result of the study shows that the hearing loss was cochlear (good SIS and absence of OAE). Also, the prolongation of latencies suggests a lesion at the level of the cochlear nucleus and above. This suggests that the cerebellar tonsils could have compressed the cochlear nucleus, which might lead to abnormal ABR results. Since cVEMP and oVEMP were absent, this also suggests possible compression at the level of the vestibular nuclei. The normal vHIT suggests that there were no peripheral abnormalities of the semicircular canals.

Thus, the results of the study show that Arnold-Chiari malformation Type I can affect the cochlear and vestibular nuclei, leading to abnormal audio-vestibular results $[14,15]$. A detailed audio-vestibular evaluation can identify the possible site of the lesion and the pathophysiology of the audio-vestibular symptoms.

\section{Conclusions}

The present study reports the results of a detailed audiovestibular evaluation in an adult female diagnosed with Arnold-Chiari malformation. The results of the study showed an abnormal prolongation of inter-peak latencies in ABR, seen in both ears. Also, cVEMP and oVEMP was absent in both ears. The results suggest possible compression of the cerebellar tonsils on cochlear and vestibular nuclei. The study suggests that individuals with ArnoldChiari malformation should undergo a detailed audio-vestibular evaluation to understand the pathophysiology of the disorder and to improve management of the condition.

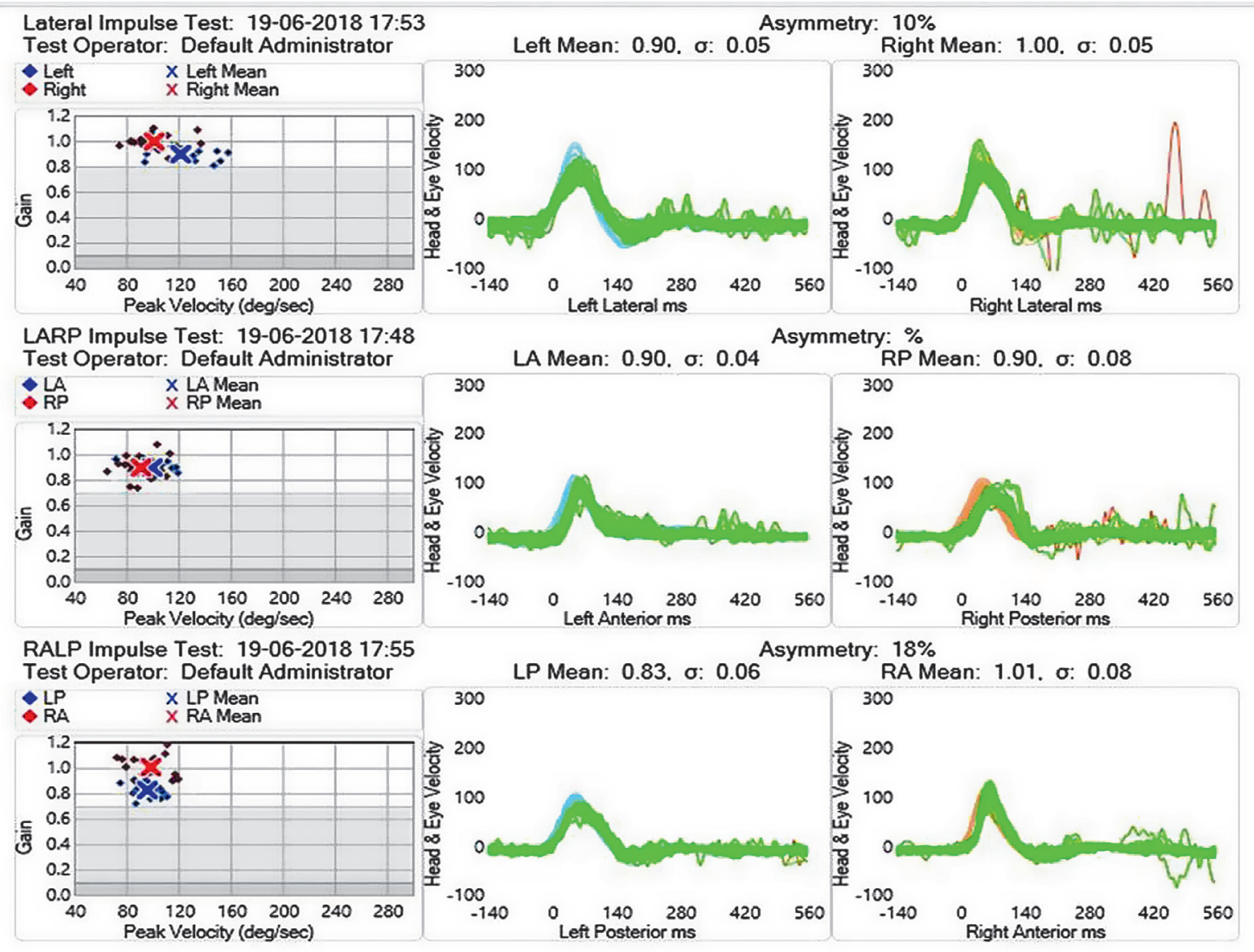

Figure 5. Video head impulse test in the patient for both ears indicating normal functioning of the three semicircular canals 


\section{References}

1. Fernández AA, Guerrero AI, Martínez MI, Vázquez MEA, Fernández JB, Octavio EC, et al. Malformations of the craniocervical junction (Chiari type I and syringomyelia: classification, diagnosis and treatment). BMC Musculoskeletal Disorders, 2009 Dec; 10(Supp1): S1.

2. Khan AA, Bhatti SN, Ahmed E, et al. Clinical and radiological findings in Arnold Chiari malformation. Journal of Ayub Medical College, Abbottabad, 2010 Jun 1; 22(2): 75-8.

3.Urbizu A, Toma C, Poca MA, Sahuquillo J, Cuenca-Leon E, Cormand B, Macaya A. Chiari malformation type I: a case-control association study of 58 developmental genes. PLoS One, $2013 \mathrm{Feb} 21$; 8(2): e57241

4. Sperling NM, Franco RA, Milhorat TH. Otologic manifestations of Chiari I malformation. Otol Neurotol, 2001 Sep 1; 22(5): 678-81.

5. Rydell RE, Pulec JL. Arnold-Chiari malformation: neuro-otologic symptoms. Arch Otolaryngol, 1971 Jul 1; 94(1): 8-12.

6. Chait GE, Barber HO. Arnold-Chiari malformation: some otoneurological features. J Otolaryngol, $1979 \mathrm{Feb} ; 8(1)$ : 65-70.

7. Mohr PD, Strang FA, Sambrook MA, Boddie HG. The clinical and surgical features in 40 patients with primary cerebellar ectopia (adult Chiari malformation). Q J Med, 1977 Jan; 46(181): 85-96.
8. Yathiraj A, Vijayalakshmi CS. Phonemically Balanced Word List in Kannada: Developed in Department of Audiology. Mysore: AIISH, 2005.

9. Singh NK, Apeksha K. Efficacy of cervical and ocular vestibular-evoked myogenic potentials in evaluation of benign paroxysmal positional vertigo of posterior semicircular canal. Eur Arch Oto-Rhino-Laryngol, 2016 Sep 1; 273(9): 2523-32.

10. Sinha SK, Barman A, Singh NK, Rajeshwari G, Sharanya R. Involvement of peripheral vestibular nerve in individuals with auditory neuropathy. Eur Arch Oto-Rhino-Laryngol, 2013 Aug 1; 270(8): 2207-14.

11. Sinha SK, Neupane AK, Gururaj K. Menstrual cycle effects on sacculocollic reflex pathway. Hear Bal Commun, 2017 Oct 2; 15(4): 252-9.

12. Hendrix RA, Bacon CK, Sclafani AP. Chiari-I malformation associated with asymmetric sensorineural hearing loss. J Otolaryngol, 1992 Apr; 21(2): 102-7.

13. Johnson GD, Harbaugh RE, Lenz SB. Surgical decompression of Chiari I malformation for isolated progressive sensorineural hearing loss. Am J Otol, 1994 Sep; 15(5): 634-8.

14. deSouza RM, Zador Z, Frim DM. Chiari malformation type I: related conditions. Neurological Res, 2011 Apr 1; 33(3): 278-84.

15. Novegno F. Clinical diagnosis-part II: what is attributed to Chiari I. Child's Nervous System, 2019 Oct 1; 35(10): 1681-93. 
Case studies • 85-90 